of complex histories of subjugation and resistance. ${ }^{2}$ While being attentive to these intersections, and the part that feminist human rights advocacy has played in reproducing other hierarchies, ${ }^{3}$ my goal in this chapter is to focus on the lineage of the dualistic and hierarchical production of sexed subjectivities in human rights discourse in order to examine how the exclusionary effects of a discourse that makes the highest claims to inclusivity have been legitimated.

\section{Lost in translation: re-scripting the sexed subjects of international human rights law}

DIANNE OTTO*

International human rights law 'sexes' its subjects, (re)producing unequal relations of gender power, but at the same time providing important opportunities for contestation and change; at least that is the hope that has sustained feminist human rights advocacy. Around the world, women's human rights campaigners have engaged assiduously with the discourse as activists, victims, policy-makers and lawyers, pushing against its masculinist and imperial underpinnings in their efforts to glimpse its emancipatory potential. This engagement has revealed that, through a variety of techniques and historical residues, women are systematically marginalized by the masculine standards and conceptions of the regime and therefore not constituted as fully human for the purposes of guaranteeing their enjoyment of human rights. ${ }^{1}$ The allegedly neutral universal subject of human rights law also reproduces other hierarchies, including those of race, culture, nation, socio-economic status and sexuality, which intersect with constructions of gender to produce subjects that bear the markings

* This chapter forms part of the requirements for JSD candidacy at Columbia University. I would like to thank my ISD Committee for their helpful comments and my partner Joan Nestle for her encouragement and support.

' V. Spike Peterson, "Whose Rights? A Critique of the "Givens" in Human Rights Discourse' (1990) 15 Alternatives 303; Karen Engle, "International Human Rights and Feminism: When Discourses Meet' (1992) 13 Michigan Journal of International Law 517; Rebecca I Cook 'Women's International Human Rights Law: The Way Forward' (1993) 15 Human Rights "Wuarterly 230; Hilary Charleswo Quarterly 230, Hilary Charlesworth, "What Are "Women's International Human Rights"? in Rebecca J. Cook (ed.), Human Rights of Women: National and International Perspectives (Philadelphia, 1994), pp. 58-84; Charlotte Bunch, 'Transforming Human Rights from a Feminist Perspective' in Julie Peters and Andrea Wolper (eds.), Women's Rights, Human Rights: International Feminist Perspectives (New York, 1995), pp. 11-17; V. Spike Peterson and Laura Parisi, 'Are Women Human? It's Not an Academic Question' in Tony Evans (ed.), Human Rights Fifty Years On: A Reappraisal (Manchester, 1998), pp. 132-60; Arvonne S. Fraser, 'Becoming Human: The Origins and Development of Women's Human Rights' (1999) 21 Human Rights Quarterly 853.
I use the terms 'sex' and 'gender' interchangeably because I want to disavow the idea that either of these categories might be natural and thus immutable, ${ }^{4}$ which is not a new insight, but one which remains deeply unacceptable to conservatives, as well as to many feminists. As Simone de Beauvoir insightfully observed in her seminal work on women's oppression, one is not born a woman but rather becomes one. ${ }^{5}$ Drawing on the work of Michel Foucault, which develops this idea, Judith Butler has argued that sex, like gender, is a social category; that the 'naturalness' of sex is produced discursively. ${ }^{6}$ To accept the idea of a sex/gender distinction that is reflective of a nature/nurture divide, as in the official UN definition, ${ }^{7}$ is to limit the manifold creative possibilities for the expression of identity, desire and sexuality opened up by releasing the category of sex from its biological foundations. Distinguishing between sex/gender in this way also misunderstands how law produces its subjects. ${ }^{8}$ There is no natural subject who precedes representation in law. Instead, legal texts and practices constitute the subjects of law, playing a particularly powerful role in the processes that (re)produce and naturalize dominant social

${ }^{2}$ Caren Kaplan, Norma Alarcón and Minoo Moallem (eds.), Between Woman and Nation: Nationalisms, Transnational Feminisms, and the State (Durham, 1999); Lisa A. Crooms, 'Indivisible Rights and Intersectional Identities or, "What Do Women's Human Rights Have to Do with the Race Convention?"' (1997) 40 Howard Law Journal 619.

${ }^{3}$ Angela P. Harris, 'Race and Essentialism in Feminist Legal Theory' (1990) 42 Stanford Law Review 581; Vasuki Nesiah, 'Toward a Feminist Internationality: A Critique of US Feminist Legal Scholarship' in Adrien Katherine Wing (ed.), Global Critical Race Feminism: An International Reader (New York, 2000), pp. 42-52.

${ }^{4}$ For a persuasive development of this position see Margaret Davies, "Taking the Inside Out: Sex and Gender in the legal Subject' in Ngaire Naffine and Rosemary J. Owens (eds.) Sexing the Subject of Law (Sydney, 1997), pp. 25-46.

5 Simone de Beauvoir, The Second Sex (ed, and trans. H. M. Parshley, New York, 1974), p. 295.

6 Judith Butler, Gender Trouble: Feminism and the Subversion of Identity (New York, 1990) pp. 7-8.

7 See UN Office of the Special Adviser on Gender Issues and Advancement of Women, 'Concepts and Definitions', http://www.un.org/womenwatch/osagi/conceptsandefinitions.htm (accessed 1 November 2005)

${ }^{8}$ Davies, 'Taking the Inside Out', p. 32. 
norms and practices, including those that normalize women's inequality. ${ }^{9}$ In order to understand how law constitutes unequal gender taxonomies and how this might be challenged, another poststructuralist insight is necessary. Building on the structuralist recognition that meaning/knowledge is created by patterns of dualistic or oppositional relationships in language ${ }^{10}$ Jacques Derrida explains how the dualisms are organized hierarchically so that one side is dominant (the 'standard') and the other side is subordinate (the 'other'). ${ }^{11}$ Derrida also emphasizes the relational quality of the dualisms; that they are interdependent. ${ }^{12}$ This means that men and women are defined in terms of each other and that changing what is understood by the feminine necessarily involves change in the masculine, and vice versa. My interest is to examine moreclosely the dynamics of the dichotomized and hierarchical gendered subjectivities that are brought into being by human rights law in order to ask how, despite a range of feminist challenges, they continue to survive.

I trace a genealogy of the female subjects of human rights law, from the earliest international instruments until the present, and examine the feminist strategies that have been employed in efforts to realize the emancipatory promises of human rights law. What emerges is not a unitary trope of 'woman', but three recurring female subjectivities, which also overlap and have otherwise complex and productive interrelationships.

1.) They are first, the figure of the wife and mother, who needs 'protection'

during times of both war and peace and is more an object than a subject of international law; econdly the woman who is 'formally equal' with men, at least in the realm of public life; and, thirdly, the 'victim' subject who is produced by colonial narratives of gender, as well as by notions of women's sexual vulnerability. These sübjectivities are produced in contradistinction to the dominant male representations that they sustain: the protected subject is constituted by her 'protector' in the form of the head of the household and, in times of war, the combatant; the formally equal subject is produced by the masculine standard against which her claims to equality are assessed; and the 'victim' subject is created by the masculine bearer of 'civilization' who rescues 'native' women from 'barbarian' men. The shifting representations of men and women achieve a remarkable

9 Carol Smart, Feminism and the Power of Law (London, 1989).

${ }^{10}$ Margaret Davies, Asking the Law Question (Sydney, 1994), pp. 231-4.

11 Jacques Derrida, Positions (trans. Alan Bass, Chicago, 1981), p. 41

12 Ibid., p. 26; see also Joan Wallach Scott, 'Gender: A Useful Category of Historical Analysis' in Joan Wallach Scott (ed.), Gender and the Politics of History (revised ed., New York, 1999), pp. 28-50. sense of unity from the consistency of the hierarchies they produce; the privileged subject always bears the masculine characteristics of the gendered duality. In fact, his dominance depends on his dissimilarity with the discourse's feminine 'others'.

These gendered personas, and their attendant hierarchies, have displayed an uncanny ability to survive, despite the best efforts of feminist legal strategists. Even as conceived by feminists, the differences of gender have repeated women's marginalization and exclusion from full humanity. The genealogy leads me to the unsettling observation that women's full inclusion in universal representations of humanity may be an impossibility so long as the universal subject (the 'standard') continues to rely for its universality on its contrast with feminized particularities (the 'other'). ${ }^{13}$ While I am not yet ready to suggest that feminist engagement with human rights law is a futile endeavour, it must be admitted that the enduring nature of these marginalized female subject positions presents a serious conundrum for women's human rights advocates. In conclusion, I offer some initial thoughts on how this conundrum might be addressed.

\section{A genealogy of international law's sexed subjects}

My starting point is that women have always been present in international legal texts; that for as long as masculine subjects have been constituted by international law, so too have women been produced as the necessary 'other' against which the masculinity of the regime's normative actors can be projected. Therefore, in 1946, when efforts to give content to the references to human rights contained in the Charter of the United Nations ('UN Charter') ${ }^{14}$ commenced with the drafting of the Universal Declaration of Human Rights (UDHR) ${ }^{15}$ advocates for women's rights did not start with a clean slate. Women had already been constituted as a subjugated category, more often implicitly than explicitly, by international legal instruments, which helped to shape what was possible in the postwar 'moment'. I begin by examining the antecedent representations of women produced by early international treaties dealing with concerns as diverse as the regulation of war, the promulgation of international labour standards and the prevention of trafficking for the purposes of

${ }^{13}$ Karen Engle, in a similar vein, wonders ' $w$ hether the periphery could ever become a part of the core without both the periphery and the core losing their appearances of coherency': Engle, 'International Human Rights and Feminism', p. 531.

14 San Francisco, 26 June 1945, in force 24 October 1945, UKTS (1946) 67.

15 General Assembly Resolution 217A(III) (1948). 
prostitution, which came to bear on the way the UDHR was to gender its subjects.

To the extent that these early legal instruments could be characterized as concerned with human rights, their preoccupation was patently with the rights of men, which meant that women were brought into being as objects of international law, rather than as its full legal subjects. Many feminists have described this object status of women aserasure or silencing, ${ }^{16}$ but this can be misleading. if it is taken-to-mean-that women were absent altogether from the legal imagination. While women were seldom produced explicitly by early legal texts, they were implicit in every representation of masculinitys as I have already suggested. Many of the boundaries, concepts and metaphors that inform international legal thinking have also played a role in the legal reproduction of the dualisms of sex, such as the division between public and private spheres and the idea of the sovereign nation-state, which privilege masculine forms of power over those associated with the feminine. ${ }^{17}$ The early treaties took a paternalistic or 'protective'18 approach to women, reconstituting traditional gender hierarchies as 'natural', thereby misrepresenting the constructed nature of human experience and removing it from discursive contestation.

The first international instruments that set out to regulate war illustrate the reproduction of sexed subjects in hierarchical relations. They were concerned almost exclusively with (male) combatants, despite the already long history of war-time sexual abuse of women. ${ }^{19}$ The only references to women were indirect, in the context of requiring an occupying power to respect 'family honour and rights. ${ }^{20}$ In conflating women

${ }^{16}$ This view is linked to the poststructuralist understanding of language that I have alluded to, which is that the repressed 'other' is literally unable to speak. I am not entirely in agreement with this view, although I would agree that the 'other' is unable to speak on her own terms, from a position of full subjectivity.

17 Hilary Charlesworth and Christine Chinkin, The Boundaries of International Law: A Feminist Analysis (Manchester, 2000); V. Spike Peterson, 'Security and Sovereign States: What is at Stake in Taking Feminism Seriously?' in V. Spike Peterson (ed.), Gendered States: Feminist (Re)Visions of International Relations Theory (Boulder, CO, 1992), pp. 31-64.

${ }^{18}$ Natalie Kaufman Hevener, 'International Law and the Status of Women: An Analysis of International Legal Instruments Related to the Treatment of Women' (1978) I Harvard Women's Law Journal 131 at 133 , used the term 'protective' as one of three analytic categories she developed to characterize treaty provisions concerned with women's status. Her other two categories were 'corrective' and 'non-discriminatory'.

19 See Kelly Dawn Askin, War Crimes against Women: Prosecution in International War Crimes Tribunals (The Hague, 1997), pp. 202-3.

${ }^{20}$ Brussels Declaration concerning the Laws and Customs of War, Brussels, 27 August 1874 Art. XXXVIII; Manual of the Laws and Customs of War on Land, Oxford, 9 September with 'family honour', women were implicitly constituted as part of the family property, making crimes against them, such as military rape or forced prostitution, an abuse of the honour of the family - a violation of the rights of the male family head - rather than abuse of women's dignity and autonomy. Women were located, together with children, the elderly and sick, in the domestic sphere as feminized civilian objects in need of manly military protection. ${ }^{21}$ Thus, the law of war naturalized a gendered distinction between the combatant and those other 'vulnerable' members of families and communities in need of his protection.

A second example of international law's early production of women as objects of masculine and legal protection is provided by the international labour standards developed during the years of the League of Nations. ${ }^{22}$ Already constituting the normative figure of the 'worker' as masculine, the 1919 Constitution of the International Labour Organization (ILO) described its goals as 'the protection of the worker against sickness, disease and injury arising out of his employment, [and] the protection of children, young persons and women'. ${ }^{23}$ The ILO went on to adopt protective instruments that banned women from night work, ${ }^{24}$ from exposure to lead ${ }^{25}$ and from working in mines, ${ }^{26}$ and mandated maternity leave for six

1880, Art. 49; Convention respecting the Laws and Customs of War on Land, 29 July 1899 , 32 Stat. 1803, Art. XLVI; Convention respecting the Laws and Customs of War on Land, 18 October 1907, entered into force 26 January 1910, 36 Stat. 2277, Art. XLVI.

21 See further, Judith G. Gardam and Michelle J. Jarvis, Women, Armed Conflict, and International Law (The Hague, 2001), pp. 97-8. For a poststructural analysis of the gendered production of the 'combatant' and 'civilian' see Helen M. Kinsella, 'Securing the Civilian: Sex and Gender in the Laws of War' in Michael Barnett and Raymond Duvall (eds.), Power in Global Governance (Cambridge, 2005), pp. 249-72.

22 Article 23(a) of the Covenant of the League of Nations calls for the provision of 'fair and humane conditions of labour for men, women, and children': Covenant of the League of Nations, as contained in Treaty of Peace between the Allied and Associated Powers and Germany, Versailles, 28 June 1919, in force 10 January 1920, 2 USTS 43 ('Treaty of Versailles').

${ }^{23}$ Preamble to the Constitution of the International Labour Organization, as contained in the Treaty of Versailles.

24 Convention No. 4: Convention concerning Employment of Women during the Night, Washington, 28 November 1919, in force 13 June 1921. The Convention was revised in 1934 (see Convention No. 41) and again in 1948 (see Convention No. 89), recognizing some exceptions.

${ }^{25}$ Recommendation No. 4: Recommendation concerning the Protection of Women and Children against Lead Poisoning, Washington, 28 November 1919.

${ }^{26}$ Convention No. 45: Convention concerning the Employment of Women on Underground Work in Mines of All Kinds, Geneva, 21 June 1935, in force 30 May 1937 
weeks following the birth of a child. ${ }^{27}$ Despite claiming to be in women's best interests, these instruments reinforced stereotypes of women's inadequacies, including assumptions about their physical weakness and their susceptibility to corruption in male-dominated workplaces. That women might need to work for their economic survival was not part of the calculus and protective policies meant that many women suffered great hardship, driving some to disguise themselves as men in order to earn a living. ${ }^{28}$ Because women's paid work was conceived as secondary to their domestic roles, it followed that men needed the 'real' jobs that provided them with a 'family' wage and women required special rules to safeguard their role (in the family and reproduction.

affich a third set of protective instruments was concerned with regulating trafficking for the purposes of prostitution. ${ }^{29}$ The impetus for these conventions, made explicit by the terminology of 'white slavery', was the trafficking of 'white' women from Europe and North America for the purposes of prostitution in Asia, Africa and South America. ${ }^{30}$ Fuelled by racism and Victorian ideas about women's sexuality, the conventions took a moralistic stand against prostitution, and the slavers were depicted as immigrant or foreign men. ${ }^{31}$ By constructing the 'problem' as one of

27 Convention No. 3: Convention concerning the Employment of Women before and after Childbirth, Washington, 28 November 1919, in force 13 June 1921; revised in 1948 (see Convention No. 103).

${ }_{28}$ Convention No. 103). Gender in Interstate and Non-Governmental Institutions (London, 1994), pp. 130-1.

${ }^{29}$ International Agreement for the Suppression of the White Slave Traffic, Paris, 18 May 1904, entered into force 18 July 1805, 1 LNTS 83; International Convention for the Suppression of White Slave Traffic, Paris, 4 May 1910, 211 Consol. TS 45; International Convention for the Suppression of the Traffic in Women and Children, Geneva, 30 September 1921, 9 LNTS 415; International Convention for the Suppression of the Traffic in Women of Full Age, Geneva, 11 October 1933, in force 24 August 1934, 150 LNTS 431. See further Nora V. Demleitner, 'Forced Prostitution: Naming an International Offense' (1994) 18 Fordham International Law Journal 163 at 164-72.

${ }^{30}$ Jo Doezema, 'Loose Women or Lost Women? The Re-Emergence of the Myth of White Slavery in Contemporary Discourses of Trafficking in Women' (2000) 18 Gender Issues 23 at 30 , notes that the term 'white slavery' was first used in 1839 in an anti-Semitic context where Jewish men were seen as responsible for trafficking European women. Demleitner 'Forced Prostitution', pp. 165-70, has a different account. She credits the use of the term to Victor Hugo, who employed it in a letter to Josephine Butler in 1870, saying ' $\mathrm{t} t \mathrm{th}$ slavery of black women is abolished in America [as if this were sol]; but the slavery of white women continues in Europe' (quoted at p. 166). Demeits the Madrid Conference, which drafted the 1910 Convention, acknowledged that it did not include women of all races, but nevertheless decided to continue to use the term, reflecting the emphasis of the reformers on 'their' women either at home or abroad.

31 Doezema, 'Loose Women or Lost Women?', pp. 29-31. slavery rather than prostitution, these instruments projected the idea that European women could not conceivably 'consent' to sex work, especially not with foreign clients. As Jo Doezema observes, the underlying motivation was not to address the problems of exploitation and abuse that women were likely to face in the unregulated sex industry, but to regulate female sexuality in the guise of protecting women. ${ }^{32}$ By ignoring the distinction between forced and voluntary sex work, these instruments produced women as unable to take care of themselves; as helpless victims needing masculine/state supervision in the form of special rules for their protection.

There is a remarkable stability in the female subjects produced by these and other early legal instruments, ${ }^{33}$ who were valued for their chastity, their prioritization of motherhood and domesticity, their acceptance of the heterosexual family hierarchy and the paternal protection of the state, its laws and its wars. In contradistinction, male figures were produced as women's defenders and moral superiors (apart from the racialized criminals who trafficked them) and the active, public, protecting masculine subject was fashioned as the marker of full humanity, autonomous and self-determining, and in no need of special rules for his protection.

Protective approaches are inconsistent with liberalism's fundamental commitment to equality, but this did not prevent their promulgation into international law by mainly European states, long after the liberal revolutions of the eighteenth century. How this can happen so seamlessly is the question at the heart of this chapter. There is a vast difference between protective measures, which treat women's secondary and dependent status as given, and affirmative measures consistent with liberal conceptions of equality, which are designed to accelerate women's enjoyment of equality with men. For example, maternity leave as a compulsory incident of motherhood is reflective of a hierarchical paternal tradition, while maternity leave available to women as of right is consistent with a framework of sex equality. Using the lens of Wesley Hohfeld's characterization of rights, protective measures directed at women are akin to a disability, as the correlative of men's immunity from being subjected to them, while affirmative measures are claim rights, which entail corresponding duties

32 Ibid., pp. 36-7.

${ }^{33}$ See also the Hague Conventions of 1902, which addressed conflicts in national laws on marriage, divorce and custody of children in a protective mode: Convention du 12 juin 1902 pour régler les conflits de loi en matière de mariage; Convention du 12 juin 1902 pour régler les conflits de lois et de juridictions en matière de divorce et de séparation de corps; Convention du 12 juin 1902 pour régler la tutelle des mineurs. 
of performance by other parties. ${ }^{34}$ A claim right is clearly more consistent with women's full humanity than placing them under a disability. Protective measures are also reminiscent of the feudal tradition in which women's submission to the family hierarchy was justified as part of the tradition of chivalry whereby obedience, and even servitude, produced a 'noble equality' and 'exalted freedom. ${ }^{35}$ 'Today, protective measures might be more persuasively defended by progressive communitarian arguments, which overlap with some feminist arguments in their emphasis on the embeddedness of individuals in their social context and prioritization of certain collective or public goods over individual rights, such as the provision of child-care. ${ }^{36}$ However, such measures are more aptly conceived as affirmative action.

Feminist debate about protection goes back to the years of the League of Nations. The protective approach was supported by many feminists who drew a parallel with the League's policies on 'natives' and 'minorities', which they understood as laying the groundwork for self-determination and eventual equality, ${ }^{37}$ in this instance misunderstanding protection as affirmative action. Indeed, women's advocates, and the gender-based non-government organizations (NGOs) they established, often played key roles in the adoption of protective treaties, ${ }^{38}$ which they argued were for women's benefit. Other feminists disagreed and instead sought to promote women's equality and non-discrimination in the enjoyment of rights, drawing from the liberal tradition. The Inter-Allied Suffrage

${ }^{34}$ Wesley Newcomb Hohfeld, Fundamental Legal Conceptions as Applied in Judicial Reasoning (ed. Walter Wheeler Cook, New Haven, 1923), pp. 35-64; Jeremy Waldron (ed.), Theories of Rights (6th ed., Oxford, 1995), pp. 6-7.

35 Edmund Burke, 'Reflections on the Revolution in France', reprinted in Jeremy Waldron, 'Nonsense Upon Stilts': Bentham, Burke and Marx on the Rights of Man (London, 1987), pp. 96-118 at p. 110.

36 Elizabeth Frazer and Nicola Lacey, The Politics of Community: A Feminist Critique of the Liberal-Communitarian Debate (New York, 1993), pp. 107-12.

37 Marilyn Lake, 'From Self-Determination via Protection to Equality via NonDiscrimination: Defining Women's Rights at the League of Nations' in Patricia Grimshaw, Katie Holmes and Marilyn Lake (eds.), Women's Rights and Human Rights: International Historical Perspectives (New York, 2001), pp. 254-75 at p. 257.

38 Felice D. Gaer, 'And Never the Twain Shall Meet? The Struggle to Establish Women's Rights as International Human Rights' in Carol Elizabeth Lockwood, Daniel Barstow Magraw, Margaret Faith Spring and S. I. Strong (eds.), The International Human Rights of Women: Instruments of Change (Washington DC, 1998), pp. 1-89 at p. 5; Jane Connors, 'NGOs and the Human Rights of Women at the United Nations' in Peter Willetts (ed.), The Conscience of the World: The Influence of Non-Governmental Organisations in the UN System (London, $1996)$, pp. $147-80$ at p. 149.
Conference ${ }^{39}$ persuaded the drafters of the Covenant of the League of Nations to support equal opportunity for women in the employment policies of the new international institution, ${ }^{40}$ but failed to have women's equality more broadly recognized. From the mid-1920s, women's groups became increasingly insistent in their opposition to protective labour legislation, pursuing instead women's equal right to work. ${ }^{41}$ The notion of women's equality and rights, as distinct from their tutelage, was discussed at the 1930 Hague Conference for the Codification of International Law in relation to promoting equal rights for women and men to retain their nationality on marriage. ${ }^{42}$ Although this proposition was rejected, it led to the adoption of a resolution that established the League's first ever committee of women to advise it on nationality issues and urged states to study the possibility of 'introduc[ing] into their law the principle of the equality of the sexes in matters of nationality. ${ }^{43}$ Pressed by women's NGOs, ten South American states then took the initiative at the international level in 1935 and presented a proposal to the League's 16th General Assembly to promulgate a convention that would promote women's civil, legal and political equality with men. ${ }^{44}$ Although action was deferred because many states remained adamant that the question of women's rights was a domestic issue, two years later the League established a Committee of Experts to undertake a comprehensive enquiry into the legal status of women worldwide. ${ }^{45}$ Unfortunately, due to the outbreak of the Second World War, the Committee met only three times and the study was never completed. The point is, however, that by the mid-1930s a nascent discourse of sex non-discrimination and women's equality was gaining ground, fostered by a growing number of women's organizations and some states. This new account emphasized the common humanity

${ }^{39}$ Margaret E. Galey, 'Forerunners in Women's Quest for Partnership' in Anne Winslow (ed.), Women, Politics and the United Nations (Westport, CT, 1995), pp. 1-10. The Inter-Allied Suffrage Conference was a joint organization of the French Women's Suffrage Union, the International Women's Suffrage Alliance and the International Council of Women.

${ }^{40}$ Covenant of the League of Nations, Art. 7.

${ }^{41}$ Whitworth, Feminism and International Relations, pp. 136-7.

42 Lake, 'From Self-Determination', p. 258.

${ }^{43}$ Resolution on the Nationality of Women, 24 January 1931, reprinted in Carol Elizabeth Lockwood, Daniel Barstow Magraw, Margaret Faith Spring and S. I. Strong (eds.), The International Human Rights of Women: Instruments of Change (Washington DC, 1998), pp. 125-6.

${ }^{44}$ Lake, 'From Self-Determination', pp. 259-62; Galey, 'Forerunners', p. 7. The states involved were Argentina, Bolivia, Cuba, Dominican Republic, Haiti, Honduras, Mexico, Panama, Peru and Uruguay.

45 Lake, 'From Self-Determination', p. 262. 
of women and men, offering women the hope of full legal subjectivity in international law, as autonomous individuals, like men, and as formally equal participants in public life.

The tension between the gender narrations of protectionism and the embryonic equality principle was, however, not the only historical dynamic that informed the drafting of the UDHR. There was also the ideological baggage that had accompanied earlier feminist efforts to improve women's status internationally as part of the 'civilizing mission' of European imperialism. ${ }^{46}$ As historian Clare Midgley notes, the formative period for modern feminism in Britain coincided with the massive expansion of British imperialism between 1790 and $1850 ;{ }^{47}$ the history of Western feminism in general, like that of international law, unfolded hand-in-hand with the colonial project whereby two-thirds of the world's population came to be subjugated to European domination. ${ }^{48}$ While early feminists, on the one hand, identified with colonized men and women by drawing on analogies with slavery to describe their own treatment, they simultaneously disavowed any identification with colonized peoples by contrasting the 'progressive' nature of British society with the backwardness of the colonies, in appealing for women's rights. ${ }^{49}$ Later, British women campaigning for suffrage drew attention to their social reform agenda for colonized women as a way to justify their inclusion in Parliament, because it would strengthen their capacity to continue the task of civilizing black and Indian women, saving them from the 'barbarian' men of the colonies and converting them to Christianity..$^{50}$

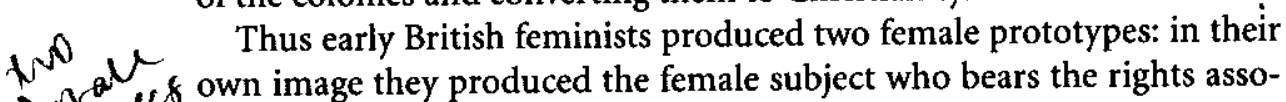
fill ciled with 'civilization', and in the image of the women of the colonies of they produced the 'victim' subject of her 'uncivilized' culture and male compatriots, whom they could better speak for and save as a result of exercising these rights. These liberal rights were, however, also committed to the project of patriarchy. While European men were full subjects of the rights, European women were placed in the contradictory position

46 See Valerie Amos and Pratibha Parmar, 'Challenging Imperial Feminism' (1984) 17 Feminist Review 3.

47 Clare Midgley, 'British Empire, Women's Rights and Empire, 1790-1850' in Patricia Grimshaw, Katie Holmes and Marilyn Lake (eds.), Women's Rights and Human Rights: International Historical Perspectives (New York, 2001), pp. 3-28.

48 Antony Anghie, 'Francisco de Vitoria and the Colonial Origins of International Law' in Eve Darian-Smith and Peter Fitzpatrick (eds.), Laws of the Postcolonial (Ann Arbor, 1999), pp. 89-107.

49 Midgley, 'British Empire', p. 7. $\quad{ }^{50}$ Ibid., p. 12. of being denied the exercise of many of those rights themselves, while willingly working as the adjuncts and helpers of 'civilized' men in the mission of imperialism, which systematically denied many others those same rights.

When the UN Charter was adopted in 1945, a new space was opened for feminist engagement with international law with the recognition of the importance of 'the equal rights of men and women ${ }^{35}$ and the commitment to 'promoting and encouraging respect for human rights and fundamental freedoms for all without distinction as to race, sex, language, or religion, ${ }^{52}$ The vision of the inclusion of all women in the global community as bearers of 'equal' rights, together with the Charter's promotion of the 'principles of equal rights and self-determination of peoples, ${ }^{53}$ promised a significant reorientation away from the protective and colonial traditions that had preceded it. The process of drafting the UDHR set the stage to test this potential, but the drafters carried with them the trappings of a complicated history of international engagement with the question of women's rights. In addition to the uneasy relationship between the discourses of protectionism and equality, they bore the markings of an imperial history that had bequeathed a woman bifurcated by colonialism. Could the idea of universality provide an opening for the emergence of a discourse that would jettison the earlier exclusionary gender tropes and constitute, instead, a fully inclusive subject in the new law of human rights? Or would the exclusionary tropes be repeated in the new guise of universal human rights?

\section{The strategy of promoting women's specificities in the new era of universality}

The newly established Commission on Human Rights (CHR) commenced the task of drafting the UDHR in 1946. Members of the Commission on the Status of Women (CSW), also established in $1946,{ }^{54}$ were active

51 UN Charter, preamble.

52 Ibid. Art. 1(3); similar references are in Arts. 13(1)(b), 55(c) and 76(c). The inclusion of sex as a category of non-discrimination was due to the efforts of women delegates from Brazil, the Dominican Republic and Mexico working through the Inter-American Commission on Women and with the NGOs who attended the Charter negotiations in San Francisco as advisers to the US delegation: see Gaer, 'Never the Twain Shall Meet?', p. 7.

53 UN Charter, Art. 1(2).

54 Margaret E. Galey, 'Women Find a Place' in Anne Winslow (ed.), Women, Politics and the United Nations (Westport, CT, 1995), pp. 11-27 at pp. 13-14. 
participants in the drafting sessions, making recommendations aimed at ensuring the inclusion of women. The CSW was made up entirely of women who, according to John Humphrey, the first Director of the Division for Human Rights, were all 'militants in their own countries' and 'acted as a kind of lobby for the women of the world, ${ }^{55}$ which made the Commission an unusually independent Charter-based body. ${ }^{56}$ The active participation of women, together with Eleanor Roosevelt's involvement as Chair of the CHR, also made the drafting process unusual. In formulating their recommendations the CSW members worked closely with women's NGOs, drawing directly on their own experience and feminist efforts during the preceding years of the League, and indirectly on at least five centuries of women's struggles for emancipation. ${ }^{57}$

At the first session of the CSW, members agreed that their goal was to 'elevate the equal rights and human rights status of women, irrespective of nationality, race, language, or religion, in order to achieve equality with men in all fields of human enterprise. ${ }^{58}$ In committing themselves to promoting women's equality, they rejected the idea that sex was an entirely natural category. Their strategy was to ensure that explicit reference was made to rights that were specific to women's experience, but within the framework of women's equality with men rather than as protective measures. ${ }^{59}$ They understood their project primarily in the context of the tensions between protectionism and equality, but their perspective was also at odds with certain premises of classical liberalism, particularly its formal approach to equality and its distinction between public and prïvate spheres. It emerged that the CSW's views clashed with those of the

55 John P. Humphrey, 'The Memoirs of John P. Humphrey: The First Director of the United Nations Division of Human Rights' (1983) 5 Human Rights Quarterly 387 at 405.

${ }^{56}$ 'The CSW's proposals to the CHR, during the drafting of the UDHR, were shaped collectively by the CSW. Among the early CSW members who played a significant role were Bodil Begtrup (Denmark, first Chairperson of the CSW), Minerva Bernardino (Dominican Republic), Hansa Mehta (India) and Amalia de Castillo Ledón (Mexico).

57 Fraser commences her historical account of the emergence of women's human rights with Fraser commences her historical account of the emergence of women's human rights with
the publication of Christine de Pizan's The Book of the City of Ladies (Le Livre de la Cité des Dames), in Europe five centuries ago: 'Becoming Human', pp. 855, 858.

58 Margaret E. Galey, 'Promoting Nondiscrimination against Women: The UN Commission on the Status of Women' (1979) 23 International Studies Quarterly 273.

59 Johannes Morsink, The Universal Declaration of Human Rights: Origins, Drafting and Intent (Philadelphia, 1999), pp. 116-29. For more critical analyses see Helen Bequaer Holmes, 'A Feminist Analysis of the Universal Declaration of Human Rights' in Caro Gould (ed.), Beyond Domination: New Perspectives on Women and Philosophy (Totowa, NJ 1983), pp. 250-64; Hilary Charlesworth, 'The Mid-Life Crisis of the Universal Declaration of Human Rights' (1998) 55 Washington and Lee Law Review 781. majority of the CHR, including Roosevelt, who felt that the general prohibition of discrimination based on sex (Article 2) was sufficient to ensure women's equal enjoyment of universal human rights, ${ }^{60}$ and that explicit references to women would weaken the position of women by undercutting the meaning of 'everyone', and introduce rights that were not 'universal' in nature. ${ }^{61}$ This majority failed to understand that their imagined universal subject was gendered; that their abstract bearer of human rights possessed masculine characteristics, which would be reflected in legal standards of equality and non-discrimination. Not unreasonably, the strategy of the CSW was to try to solve this problem by having women's specific human rights recognized as universal.

An initial concern for the CSW was the use of masculine pronouns in the early drafts of the UDHR, which explicitly gendered the universal subject; ${ }^{62}$ a linguistic point that is often trivialized, but has often proved to be determinative. In the tradition of Olympe de Gouges, who rewrote the French Declaration of the Rights of Man and the Citizen by using the Frencinclusive language in $1791{ }^{63}$ they refused to accept anything less than explicit inclusion. As Roosevelt later recalled, the CSW representhan explicit inclusion. Aal "all men," when we get home it will be "all men"'64 Eventually, it took an unprecedented intervention from the UN Secretary-General, at the urging of the CSW, before the CHR agreed to change the opening words of the first article from 'all men' to 'all people, change the opening words of the first an $1948{ }^{65}$ The wording that was transmitted to the Economic and Social Council for approval, and eventually adopted by the General Assembly, used 'all human beings'.66 The CSW's concern with inclusive language was consistent with their equality approach because, as they saw it, if women were explicitly included as bearers of all human rights, it would be more difficult to relegate them to special categories requiring protection (or salvation). Their victory on

60 Johannes Morsink, 'Women's Rights in the Universal Declaration' (1991) 13 Human Rights Quarterly 229 at 231-2.

61 Lake, 'From Self-Determination', p. 265

${ }^{62}$ For a feminist analysis of the use of masculine terms as generic, see Holmes, 'Feminist Analysis', pp. 259- 61

${ }^{63}$ Olympe de Gouges, 'Declaration of the Rights of Woman and the Female Citizen' (1791), reprinted in Carol Elizabeth Lockwood, Daniel Barstow Magraw, Margaret Faith Spring reprinted in Carol Elizathe International Human Rights of Women: Instruments of Change (Washington DC, 1998), pp. 90-7.

(Washington DC, 1998), pp. 90-7. ${ }^{64}$ Gaer, 'Never the Twain Shall Meet?', p. 10, quoting Eleanor Roosevelt, 'Making Human
Rights Come Alive', Speech to the Second National Conference on UNESCO, Cleveland, Ohio, 1 April 1949.

65 Morsink 'Women's Rights', p. $235 . \quad 66$ Ibid., pp. 235-6. 
gendered language was, however, only partial, and the masculine pronoun remained in fourteen of the UDHR's thirty articles. ${ }^{67}$ The stubbornness (or was it optimism?) of the members of the CHR on this matter, most of whom were deeply committed to the idea of human rights, attests to the continuing power of the discourse of gender naturalization.

The CHR's refusal to specify that masculine pronouns were inclusive of the feminine, which the CSW had also suggested, ${ }^{68}$ left the CSW with the task of negotiating the wording of every article in their attempts to ensure that the rights of women were included. Despite their efforts, there is only one direct reference to the equal rights of women which, significantly, appears in the context of the family ${ }^{69}$ Article 16 recognizes the 'equal rights' of men and women 'as to marriage, during marriage, and at its dissolution'. The 3rd Committee of the General Assembly, not the $\mathrm{CHR}$, was responsible for the ultimate formulation, which survived by a very close vote despite resistance from Christian groups to the reference to divorce. ${ }^{70}$ The recognition of equality between women and men in family relations was unprecedented. Although John Stuart Mill had famously argued for equality within marriage in $1869,{ }^{71}$ his lead had generally not been followed, ${ }^{72}$ and liberalism's continued treatment of the domestic sphere as a private and unregulated space presented a major conceptual barrier to women's enjoyment of human rights. ${ }^{73}$ Communitarian traditions have been even less likely to be concerned with equality within families, tending to exemplify the most oppressive features of family rela-. tions rather than opening them to scrutiny. ${ }^{74}$ Therefore, the wording of Article 16 was a significant achievement, moving, as it does, against the grain of the major traditions that informed the drafting of the UDHR and challenging the purported innateness of gender hierarchies.

${ }^{67}$ UDHR, Arts. 8, 10,11(1), 12, 13(2), 15(2), 17(2), 18, 21(1), 22, 23(3), 25(1), 27(2) and

$29(1)$ and (2).
68 Morsink, 'Women's Rights', pp. 231-2.

69 There is also a reference to the equal rights of men and women in the preamble to the UDHR, but even this was only included after a struggle, despite merely repeating the wording in the UN Charter: see Morsink, 'Women's Rights', p. 232.

70 Ibid., p. 248.

71 John Stuart Mill, The Subjection of Women (ed. Pamela Frankau, London, 1970), pp. 219 317 at p. 259.

${ }_{72}^{72}$ Martha C. Nussbaum, Sex and Social Justice (New York, 1999), p. 65.

${ }^{73}$ Celina Romany, 'State Responsibility Goes Private: A Feminist Critique of the Public/Private Distinction in International Human Rights Law' in Rebecca J. Cook (ed.) Human Rights of Women: National and International Perspectives (Philadelphia, 1994), pp. 85-115.

${ }^{74}$ Frazer and Lacey, Politics of Community, pp. 139-40.
Unfortunately, however, the trope of the wife and mother, in need of male protection, also survived in the text of the UDHR. The description of the family as 'the natural and fundamental group unit of society ${ }^{75}$ reintroduces the suspect language of nature, masking the political character of the family and suggesting that it is exempted (still) from human rights scrutiny. Further, the CSW recommendation that any special provisions relating to motherhood be framed as 'rights' or 'benefits', as an alternative to treating maternity as a disability requiring 'protection', was not adopted. ${ }^{76}$ The protected subject also makes her appearance in Article 25 , which recognizes that everyone [sic] has the right to an adequate standard of living for "himself and his family." ${ }^{\text {?7 }}$ Conflicting with the Article 16 guarantee of equal marriage rights, these provisions give renewed life to the protected female subject and the masculine figure of the household head and breadwinner who still needs a family wage in the era of universal human rights.

The CSW's acceptance of these provisions suggests some continuing ambivalence in the feminist imagination about protective (affirmative?) conceptions of women, especially when it comes to motherhood. This ambivalence is also apparent in the CSW's failure to promote rights associated with women's physical integrity and sexual autonomy, which left the UDHR silent on gendered violence and reproductive rights. At least in hindsight, these omissions are hard to understand, presuming the drafters had knowledge of the sexual violence directed at women during the Second World War, including the Japanese system of 'comfort women' and the Nazi practices of forcing abortions on non-Aryan women. The Nazis' targeting of homosexual women and men for extermination also makes the failure to protect rights associated with sexuality, in retrospect, unfathomable. The drafters left these matters, if they thought about them at all, in the uncertain custody of privacy rights. ${ }^{78}$ These 'blind spots' attest to the powerful way that protective gender narratives work to prevent the abuses perpetrated by putative protectors - husbands, doctors and religious leaders - being classified as human rights violations.

In seeking to ensure that women's rights were explicitly recognized in the UDHR, the CSW delegates were confronted with the difficult,

${ }^{75}$ UDHR, Art. 16(3). $\quad{ }^{76}$ Lake, 'From Self-Determination', pp. 266-7.

77 Morsink, Universal Declaration of Human Rights, p. 120, notes that the CSW did not object to the masculine language of the phrase 'himself and his family' which is used in both Arts. 23 and 25 because the concept of the family wage was so widely supported.

${ }^{78}$ Article 12 protects against 'arbitrary interference with his [sic] privacy, family, home or correspondence'. 
perhaps impossible, task of conceptualizing women's different experience in a framework of equality; pressing against the established discourses of protection, salvation and formal equality. To this end, they made a number of proposals for explicit references to women's equality in the the public sphere context. ${ }^{79}$ While their efforts resulted in several important references to equality in the UDHR's substantive provisions, ${ }^{80}$ they do not achieve the CSW's goal of including rights that are specific to women's gendered experience. Making matters worse, there is no indication in the UDHR that equality is to be understood substantively, and there is no provision for affirmative action measures. While there is an emerging consensus today that equality and nondiscrimination in human rights law are substantive concepts, ${ }^{81}$ the gendered subjects produced by the UDHR in 1948 were formally equal, which left women's differently gendered experience in the realm of protection.

The markings of the imperial inheritances of international law and Western feminism also survived in the UDHR. In keeping with their mandate, the CSW sought to promote the rights of women 'irrespective of nationality, race, language or religion'. They argued on several occasions for the inclusion of non-discrimination clauses that made reference to other forms of discrimination, in addition to sex discrimination. ${ }^{82}$ Despite this clarity about what would today be described as 'intersectional' forms of discrimination, ${ }^{83}$ the CSW's reliance on non-discrimination to do all the work of ensuring the inclusion of women's diversities (beyond gender differences) merited the same critique as the one they applied to the CHR's view that prohibiting sex discrimination was enough to ensure women's equal enjoyment of human rights. That is, without specific acknowledgment that women's human rights abuses may have intersectional dimensions, the purportedly universal subject is not only reflective of the privileged gender group, but also bears the characteristics of

79 Morsink, Universal Declaration of Human Rights, p. 243 (legal personality), pp. 250-2 (political participation) and pp. 252-5 (conditions of work and remuneration).

${ }^{80}$ See for example Arts. 21(3), 23(2) and 26(1).

81 Dianne Otto, "Gender Comment": Why Does the UN Committee on Economic, Social and Cultural Rights Need a General Comment on Women?' (2002) 14 Canadian Journal of Women and the Law 1; Titia Loenen, 'Rethinking Sex Equality as a Human Right' (1994) 3 Netherlands Quarterly on Human Rights 253.

82 Morsink, 'Women's Rights', pp. 244, 251-2.

${ }^{83}$ Kimberle Crenshaw, 'Demarginalizing the Intersection of Race and Sex: A Black Feminist Critique of Antidiscrimination Doctrine, Feminist Theory and Antiracist Politics' (1989) University of Chicago Legal Forum 139. privileged race, class and sexuality groups. ${ }^{84}$ While this oversight may be partly attributable to the experience of the CSW women, the problem goes much deeper, to the heart of the idea of universality: whether it is possible to conceive of a universal subject that is fully inclusive.

The privileging of European experience is amply evident in the architecture of the UDHR. Although economic and social rights are recognized as universal, the UDHR gives priority to civil and political rights, in their numerical majority and their placement before economic and social rights. Its focus on individual human rights, despite the communitarian character of most, if not all, non-European traditions, raises a number of problems for feminists as well as for communitarian traditions. For feminists, the paradigm of individual rights obfuscates the structural dimensions of hierarchal arrangements of power, misrepresenting institutionalized and systemic disadvantage as a problem that can be solved by individual rights claims. ${ }^{85}$ Further, the essentially competitive nature of individual rights makes them 'anti-socialistic', ${ }^{86}$ leading to winners and losers rather than to collective solutions more in keeping with many communitarian and feminist ideals. While the experiences of fascism and the rising totalitarianism of communist states gave the protection of individual rights a particular urgency in the Europe of 1948, it did not justify almost totally ignoring collective conceptions of rights and obligations. In marking the autonomous individual as the highest ideal of 'civilization' the UDHR doubly reinstated the colonial paradigm of masculinity; of European superiority and of the feminized 'yictim' subject in need of rescue from her own communal culture. The 'spirit' of rights that is present in every cultural tradition ${ }^{87}$ was thus erased from the text and, along with it, women's histories of resistance to patriarchal arrangements in non-European and colonial societies. ${ }^{88}$

The marginalized female subjects produced by the UDHR - in need of protection, or imperial salvation, or relegated to a position of formal equality with men - were repeated, with little change, in the

${ }^{84}$ Ibid.

${ }^{85}$ Nicola Lacey, Unspeakable Subjects: Feminist Essays in Legal and Social Theory (Oxford, 1998), p. 27.

${ }^{86}$ Ibid.

${ }^{87}$ Leslye Amede Obiora, 'Panel Discussion: How Does the Universal Declaration of Human Rights Protect African Women?' (1999) 26 Syracuse Journal of International Law and Commerce 195 at 208.

${ }^{88}$ Marjorie Mbilinyi, 'Runaway Wives in Colonial Tanganyika: Forced Labour and Forced Marriage in Rungwe District 1919-1961' (1988) 16 International Journal of the Sociology of Law 1 at 3. 
translation of its provisions into legally binding instruments: the International Covenant on Economic, Social and Cultural Rights (ICESCR) ${ }^{89}$ and the International Covenant on Civil and Political Rights (ICCPR). ${ }^{90}$ Both Covenants, like the UDHR, explicitly gender the universal subject and rely primarily on a general prohibition of sex discrimination as the means to ensure women's equal enjoyment of the rights they enumerate. ${ }^{91}$ However, the continued efforts of the $\mathrm{CSW}^{92}$ did result in a stronger emphasis on equality between women and men with the inclusion of common Article 3, which requires States Parties to ensure 'the equal right of men and women to the enjoyment of all ... [rights] set forth in the present Covenant'. This article repeats the UN Charter's reference to the 'equal rights of men and women', which had been relegated to the preamble to the UDHR, and the choice of the word 'enjoyment' suggests substantive rather than formal equality. ${ }^{93}$ The CSW also succeeded in having the UDHR's affirmation of equal marriage rights guaranteed by Article 23 of the ICCPR. ${ }^{94}$ However, during the drafting of the Covenants, the energies of the CSW and women's NGOs were primarily focused elsewhere in the programme of work of the CSW, ${ }^{95}$ which was moving towards the formulation of separate conventions promoting women's equality with respect to political and nationality rights ${ }^{96}$ and the preparation of what would become the General Assembly Declaration on the Elimination of Discrimination against Women. ${ }^{97}$ Paradoxically, the establishment of a separate institutional focus for women was having the effect of weakening the advocacy for women in general human rights forums.

${ }^{89}$ New York, 16 December 1966, in force 3 January 1976, 993 UNTS 3.

${ }_{91}^{20}$ New York, 16 December 1966, in force 23 March 1976, 999 UNTS 171

91 Ibid., Art 2(1); ICESCR, Art. 2(2).

92 Connors, 'NGOs and the Human Rights of Women'.

93 The ICCPR also takes two further steps: it makes clear that the prohibition of sex discrimination is among the norms that are non-derogable in times of public emergency (Art. $4(1)$ ) and extends the norm of sex non-discrimination to children (Art. 24(1)).

${ }_{95}$ Connors, 'NGOs and the Human Rights of Women', p. 154.

95 Ibid., p. 153.

${ }^{96}$ Convention on the Political Rights of Women, New York, 31 March 1953, in force 7 July 1954, 193 UNTS 135; Convention on the Nationality of Married Women, New York, 20 February 1957, in force 11 August 1958, 309 UNTS 65. Despite the formal affirmation of equality in the convention on women's political rights, a memorandum of the Secretary General still treated the granting of political rights to women as a grant of privilege or protection: see Carrie DeBehnke in Carol Elizabeth Lockwood, Daniel Barstow Magraw, Margaret Faith Spring and S. I. Strong (eds.), The International Human Rights of Women Instruments of Change (Washington DC, 1998), pp. 181-2.

${ }^{97}$ GA Res. 2263 (XXII), 7 November 1967.
Outside the substantive equality approach of common Article 3, both Covenants make few specific references to women. When such references are made, they either compromise women's equality by taking a protective or imperial approach, or introduce narratives that restrict equality to its formal sense. For example, while equality in marriage is recognized, it is contradicted by protective conceptions of women in association with pregnancy and childbirth ${ }^{98}$ and the continued framing of the right to an adequate standard of living as a right that is due to a man, as the household head. ${ }^{99}$ Further, the weaker enforcement obligations of the ICESCR magnify the qualified approach of the UDHR to this category of rights, revealing an underlying commitment to the market economies of capitalism and reducing social responsibility for the enjoyment of economic, social and cultural rights, an approach that impacts disproportionately opiwomen, especially poor women.

In sum, the approach taken by the CSW - to ensure women's inclusion in the universal coverage of human rights by seeking explicit reference to women's rights within an overarching framework of equality - did not prevent the reinvigoration of all three of the marginalized female subjectivities produced by the earlier instruments. The main subject of human rights law, the generic bearer of universal rights, remained tenaciously masculine. Nevertheless, there were also some important changes, including the opening up of the private sphere to human rights scrutiny, and formal equality replacing protectionism as the dominant approach. But it must be asked whether the persistence of marginalizing representations of women suggests that the discourse of human rights is itself built on histories and structures of domination and therefore, ironically, reliant on the reproduction of hierarchical gender subjectivities? Or could the development of more substantive conceptions of gender equality still provide an opening for the inclusion of women's rights? These are questions that the next strategy of women's rights advocates tried to address.

\section{The strategy of substantive equality by means of a specialized women's human rights instrument}

The masculinity of the generic subject of human rights law produced by the Universal Bill of Rights - the UDHR, ICCPR and ICESCR - had serious practical consequences. It meant that women's enjoyment of human rights was seldom addressed by UN human rights bodies despite the growing

${ }^{98}$ ICESCR, Art. 10(2). $\quad 99$ Ibid., Art. 11(1). 
number of formal commitments to women's equality, ${ }^{100}$ while it was clear that women's disadvantage was persisting, and in some cases worsening. ${ }^{101}$ This dismal state of affairs led to the second major attempt by feminists to achieve women's inclusion as full subjects of human rights law: the promulgation of a convention that would promote women's substantive equality with men. While this idea had its antecedents in the conventions drafted earlier by the CSW encouraging women's equal enjoyment of political and nationality rights, and in the General Assembly's 1967 Declaration, it was the first time that the achievement of women's substantive equality was a clear, albeit still contested, goal. In the hopeful context of the UN's International Decade for Women (1976-85), the Convention on the Elimination of All Forms of Discrimination against Women (CEDAW) was adopted by the General Assembly and opened for ratification in $1979 .{ }^{102}$ Its preamble expressed concern that 'extensive discrimination against women' continues to exist, despite states' obligations under the human rights covenants to ensure the equal rights of men and women and despite the adoption of other international conventions, resolutions, declarations and recommendations promoting equality between women and men.

In examining the approach that CEDAW takes to the issues of gender representation and hierarchy that I have raised, it must first be observed that the formal equality approach of the general human rights instruments remains prominent. In urging the prohibition of all forms of discrimination against women, the CEDAW adopts a template of comparison with men that continues to tie women's rights to comparisons with a universal standard that is cast in masculine terms. ${ }^{103}$ At the same time, the project of treating women differently within the framework of equality is also advanced, which requires some reconceptualization of the universal subject. The drafters of CEDAW tackled this project in two ways: by challenging the conceptual boundaries of human rights law, and by explicitly reconstituting the universal subject as a woman. The task of reconceptualizing boundaries is commenced by expanding the definition of discrimination against women by ensuring that both direct and indirect

${ }^{100}$ Margaret E. Galey, 'International Enforcement of Women's Rights' (1984)6 Human Rights Quarterly 463.

${ }^{101}$ See for example Ester Boserup, Women's Role in Economic Development (New York, 1970).

${ }_{102}$ New York, 18 December 1979, in force 3 September 1981, 1249 UNTS 13.

${ }^{103}$ Hilary Charlesworth, Christine Chinkin and Shelley Wright, 'Feminist Approaches to International Law' (1991) 85 American Journal of International Law 613 at 631, 'the underlying assumption of its [CEDAW's] definition of discrimination is that women and men are the same? forms of discrimination are included and defining the goal substantively, as directed towards women's 'enjoyment' and 'exercise' of human rights and fundamental freedoms. ${ }^{104}$ Other CEDAW provisions also make reference to 'the practical realization' of equality between women and men ${ }^{105}$ and 'effective protection' against discrimination. ${ }^{106} \mathrm{~A}$ strong endorsement of affirmative action further underlines the goal of substantive equality, ${ }^{107}$ although the 'temporary' character of such measures must be questioned in light of women's entrenched disadvantage and the long-term nature of the project of dismantling gender hierarchies. ${ }^{108}$ Different treatment for the purposes of affirmative action is distinguished from protectionism in its extreme form by cautioning against 'the maintenance of unequal or separate standards. ${ }^{109}$ While the argument that equality can result from separate-but-equal treatment was supported by a coalition of conservative religious states at the Fourth World Conference on Women, ${ }^{110}$ advocates of women's equality would agree that this approach is unacceptable. As Martha Nussbaum observes, it 'usually ends up endorsing a division of duties that is associated with traditional forms of hierarchy." ${ }^{111}$ Finally, CEDAW is emphatic in its prohibition of discrimination in the private sphere, ${ }^{112}$ rejecting the boundary between public and private spheres that has served to perpetuate protective ideas about women.

The CEDAW also (re)interprets human rights in order to reconstitute its subject as a woman. For example, in the sphere of work, unfair dismissal is (re)defined to include dismissal on the grounds of pregnancy, maternity leave and marital status, ${ }^{113}$ and providing social service supports for workers is (re)defined to include the provision of child-care

104 CEDAW, Art. $1 . \quad{ }^{105}$ Ibid., Art. 2(a). $\quad{ }^{106}$ Ibid., Art. 2(c).

${ }^{107} \mathrm{lbid}$., Art. 4(1), declares 'temporary special measures aimed at accelerating de facto equal ity between men and women' not to be discriminatory under the Convention, so long as they do not entail 'the maintenance of unequal or separate standards'.

${ }^{108}$ Committee on the Elimination of Violence against Women ('CEDAW Committee'), General Recommendation No. 25 (30 January 2004), UN Doc. CEDAW/C/2004/I/WP.1/Rev. 1 , resolves this problem in two ways. First, it distinguishes between temporary special measures and other 'general social policies' to improve the status of women which cannot be considered temporary special measures (para. 19). Secondly, it acknowledges that 'temporary' may mean 'a long period of time', as long as the measures are functionally necessary (para. 20).

${ }^{109}$ CEDAW, Art. 4(1).

110 Dianne Otto, 'Holding Up Half the Sky, But For Whose Benefit?: A Critical Analysis of the Fourth World Conference on Women' (1996) 6 Australian Feminist Law Journal 7 at $14-15$.

I'I Nussbaum, Sex and Social Justice, p. 51.

112 CEDAW, Art. 1, does not limit its prohibition of discrimination to the public sphere.

113 Ibid., Art. $11(2)(a)$. 
facilities. ${ }^{114}$ Similarly, with respect to ensuring women's equal enjoyment of the right to education, gender-specific issues must be addressed, like eliminating stereotypical gender representations from educational materials ${ }^{115}$ and implementing school retention strategies that are directed specifically at women and girls. ${ }^{116}$ Nicola Lacey describes the approach in CEDAW as 'subtly positioned . . . between a universal conception of human rights and a woman-centred political focus.'177 However, in some cases CEDAW goes beyond this balancing act and dispenses altogether with the model of comparison with men, as when addressing the issues of pregnancy and motherhood. For example, 'maternity leave with pay or comparable benefits' must be available 'without loss of employment, seniority or social allowances,, ${ }^{118}$ and women's health-related rights include autonomous access to appropriate reproductive health care services, not conditioned on equality with men. ${ }^{119}$ These provisions grant women claim rights, rather than special benefits or privileges and, in so doing, reimagine the universal subject by recognizing universal rights that may not be relevant to men.

Building on these and other textual opportunities, the CEDAW Committee has strengthened CEDAW's substantive equality framework by adopting General Recommendations that advance the project of reimagination by further releasing CEDAW's subject from comparisons with men. For example, General Recommendation 16 urges States Parties to recognize and value women's unpaid economic contributions and makes it clear that the Committee considers unpaid work in family enterprises to be a form of exploitation of women that is contrary to CEDAW..$^{120}$ In the same vein, General Recommendation 24 insists that States Parties must implement health measures that address the distinctive features and factors that differ for women in comparison to men', breaking out of the paradigm that has recognized women's different health needs only in connection with pregnancy and motherhood. ${ }^{121}$. The CEDAW Committee

114 Ibid., Art. 11(2)(c). ${ }^{115}$ Ibid., Art. 10(c). $\quad{ }^{116}$ Ibid., Art. 10(f).

117 Nicola Lacey, 'Feminist Legal Theory and the Rights of Women' in Karen Knop (ed.), Gender and Human Rights (Oxford, 2004), pp. 13-55 at p. 22.

118 CEDAW, Art. 11(2)(b).

119 Ibid., Arts. 11(2)(b) and 12(2); see further Arts. 10(h), $11(1)(f)$ and $11(2)(d)$.

120 CEDAW Committee, General Recommendation 16 (2 January 1991), as contained in UN Doc. A/46/38; see also CEDAW Committee, General Recommendation 17 ( 3 January 1991 ), as contained in UN Doc. A/46/38.

121 CEDAW Committee, General Recommendation 24 (2 February 1999), as contained in UN Doc. A/54/38/Rev. i, para. 12; see further, CEDAW Committee, General Recommendation 14 (2 February 1990), as contained in UN Doc. A/45/38 (on female circumcision). has also declared its intention to treat violence against women as a form of discrimination against women that is prohibited by CEDAW, ${ }^{122}$ and found violations of CEDAW in a case of domestic violence, ${ }^{123}$ submitted under the new Optional Protocol that allows individual complaints. ${ }^{124}$ These interpretations directly counter the production of marginalized subject positions as an acceptable response to women's specificities and give life to a more gender-inclusive universal subject.

Nevertheless, despite the innovative and detailed elaboration of substantive equality by CEDAW, all three of the marginalized subjectivities remain. I have already made reference to the subject who is formally equal with men, evident in many of CEDAW's provisions, despite the commitments to equality in a substantive sense. The ultimate goal of CEDAW still appears to be formally equal treatment, which, as Frances Olsen has usefully explained in another context, disrupts the rigid 'sexualizations' of the dualisms of gender by imagining that women can assume the roles and characteristics that have traditionally been thought of as men's, but does nothing to challenge the 'hierarchization' of sexed activities. ${ }^{125}$ The movement imagined by formal equality is only one-way, contending that women should enjoy the same rights as men if they choose to enter the public sphere. It is instructive that there is not a parallel concern to ensure that men's choice to be 'like women' in domestic matters leads to the enjoyment of rights equal to those that women enjoy.

Protective representations of women also survive through a number of techniques. The first is the requirement of the 'suppress[ion] ... of the exploitation of prostitution of women. ${ }^{126}$ This provision does not recognize the rights of women, either as victims of forced prostitution or as workers in the sex industry. Instead, it casts all prostitution as 'exploitation' and all 'prostitutes' as always already needing protection. Such over-simplification of the complexity of women's economic decision-making not only denies women agency, but also reflects the same gendered anxieties about women's sexuality as the earlier anti-trafficking

122 CEDAW Committee, General Recommendation 12 (6 March 1989), as contained in UN Doc. A/44/38, para. 1; updated and extended by CEDAW Committee, General Recommendation 19 (29 January 1992), as contained in UN Doc. A/47/38, para. 23.

123 CEDAW Committee, Communication No. 2/2003, Ms A. T. v. Hungary, as contained in UN Doc. CEDAW/C/32/D/2/2003 (26 January 2005).

124 Optional Protocol to the Convention on the Elimination of All Forms of Discrimination against Women, New York, 15 October 1999, in force 22 December 2000.

125 Frances Olsen, 'Feminism and Critical Legal Theory: An American Perspective' (1990) 18 International Journal of the Sociology of Law 199 at 202-3.

126 CEDAW, Art. 6. 
instruments. ${ }^{127}$ The article is placed with the general provisions in Part I of CEDAW, which gives this protective representation a troubling prominence. The CEDAW also condones protective labour legislation, a position that is not improved by the stipulation that States Parties periodically review its continuation 'in the light of scientific and technological knowledge. ${ }^{128}$ By predicating change on the advice of technical and scientific experts, the provision doubly removes women from making their own decisions about where and when they will work. Protective approaches are also indirectly kept alive by many of the sweeping reservations that States Parties have entered in order to limit their obligations under CEDAW. ${ }^{129}$ Article 16, which promotes equality in the context of marriage and the family, is the most highly reserved of the substantive provisions, evidencing strong resistance to equality in the domestic sphere and an enduring resolve to continue treating women as objects of masculine protection.

The 'victim' subject of the discourse of (neo)colonialism is also evident in CEDAW. She overlaps, to some extent, with the protected figure of the prostitute in that the problem driving the adoption of Article 6 in 1979 was no longer the 'white' slave trade but the movement of women from developing countries to the West. ${ }^{130}$ The motivation to rescue these new 'victims' was fuelled by depictions of them as backward, naïve, helpless, tradition-bound and lacking the sophistication to make a rational decision to work in the sex industry. ${ }^{131}$ Such images have continued to have powerful effects, keeping alive a distinction between Western women and those native 'others' who still need the West to speak for them and arrange for their escape from 'foreign' criminals and, in some narratives, also from their own conniving (uncivilized) families. ${ }^{132}$ Thus, the woman bifurcated by colonialism continues in the 'postcolonial' era, embedded in the assumptions of the premier instrument of women's human rights.

Perhaps the most important article in CEDAW is Article 5, which recognizes that women's equality will not be achieved without changes in the social and cultural production of gender stereotypes 'based on the idea of

${ }^{127}$ Doezema, 'Loose Women or Lost Women?', pp. 40-1.

${ }^{128}$ CEDAW, Art. 11(3).

${ }^{129}$ See for example reservations by states that condition their compliance on CEDAW's consistency with Islamic Shariah law, like Egypt and Libya.

130 Doezema, 'Loose Women or Lost Women?', p. 37.

1.31 Ibid.; Kapur, 'Tragedy of Victimization Rhetoric', p. 19

${ }^{132}$ For a telling example of the perpetuation of the imperial 'victim' subject in this context, see the material of the Coalition against Trafficking in Women, http://www. catwinternational.org (accessed 1 November 2005); contra Global Alliance against Traffic in Women, http://www.gaatw.org (accessed l November 2005). the inferiority or the superiority of either of the sexes. This provision is extremely useful in its recognition that gender is a social category and that the problem is one of gender hierarchies, rather than gender differences per se. However, the references to 'culture' as the source of stereotyped gender attitudes and 'custom' as the basis for discriminatory practices, ${ }^{133}$ have also worked to silence women's histories of engaging culture and tradition resistively as a source of empowerment. ${ }^{134}$ While the use of culture can be profoundly conservatizing, it can also help change to occur. The provision is often read by Western feminists to justify efforts to 'abolish' non-Western cultural practices, as if that were possible, rather than, as Celestine Nyamu suggests, seeking to 'engage with the specific politics of culture. ${ }^{135}$ This demonizing of non-Western cultures gives sustenance to neo-colonial narratives of women as the powerless 'victims' of their own tradition.

The continued marginalization of women from the universal frame of human rights, despite the adoption of a treaty specifically to promote women's equality and the innovative efforts of the CEDAW Committee to promote the understanding of that equality in substantive terms, prompted another re-evaluation by feminists in the late 1980s. This led to the emergence of the third feminist inclusion strategy - the claim that women's-rights-are-human-rights. ${ }^{136}$ The dual goals of the new strategy were to have gender-specific rights abuses explicitly recognized as human rights violations, and to refocus attention on ensuring the application of the general human rights instruments to women by promoting the 'mainstreaming' of women's human rights. ${ }^{137}$ This brought the struggle for women's inclusion in the discourse of universal human rights back to

133 CEDAW, Art. 5(a)

134 L. Amede Obiora, 'Reconsidering African Customary Law' (1993) 17 Legal Studies Forum 217; J. Oloka-Onyango and Sylvia Tamale, "'The Personal is Political," or Why Women's Rights Are Indeed Human Rights: An African Perspective on International Feminism' (1995) 17 Human Rights Quarterly 691.

1.35 Celestine I. Nyamu, 'How Should Human Rights and Development Respond to Cultural Legitimization of Gender Hierarchy in Developing Countries?' (2000) 41 Harvard International Law Journal 381 at 417 . See further Leti Volpp, 'Feminism versus Multiculturalism' (2001) 101 Columbia Law Review 1181.

136 Charlotte Bunch, 'Women's Rights as Human Rights: Toward a Re-Vision of Human Rights' (1990) 12 Human Rights Quarterly 486 at 496 , notes the use of the phrase 'women's rights are human rights' by the GABRIELA women's coalition in the Philippines in 1989, and by a panel stating that 'Violence Against Women is a Human Rights Issue' at a conference organized by International Women's Rights Action Watch in 1990.

137 Radhika Coomaraswamy, Reinventing International Law: Women's Rights as Human Rights in the International Community (Cambridge, MA, 1997), p. 9. 
where it began, to the strategy that the CSW adopted in 1946, which sought to ensure that explicit reference was made to rights that were specific to women's experience within the general framework of equality and universality. Could a renewed focus on constituting women's specific rights as human rights dislodge the masculine form of the universal subject, when earlier efforts to do this had failed?

\section{The strategy of women's-rights-are-human-rights}

The claim, women's-rights-are-human-rights, had widespread resonance. It became a new rallying point for women's human rights advocates in the late $1980 \mathrm{~s}^{138}$ and, in the years leading up to the 1993 World Conference on Human Rights, hundreds of thousands of women were mobilized in over one hundred countries to claim women's rights as human rights. ${ }^{139}$ The language itself was formally adopted by states, first in $1993,{ }^{140}$ and then at the 1995 Fourth World Conference on Women ('Beijing Conference'). ${ }^{141}$ The claim, also expressed in the assertion of the 'indivisibility' of women's human rights, ${ }^{142}$ insists that women's rights are universal. This new feminist strategy can be situated within a broader movement in the post-Cold War era to utilize human rights discourse to defend against new threats to human dignity and survival posed by the hegemony of global capital ${ }^{143}$ and the erosion of the discourse itself. ${ }^{144}$ These

138 Gaer, 'Never the Twain Shall Meet?', p. 19.

139 Elisabeth Friedman, 'Women's Human Rights: The Emergence of a Movement' in Julie Peters and Andrea Wolper (eds.), Women's Rights, Human Rights: International Feminist Perspectives (New York, 1995), pp. 18-35.

140 Vienna Declaration and Program of Action, World Conference on Human Rights, UN Doc. A/CONF.157/23 (1993), Part I, para. 18 ('Vienna POA').

141 Beijing Declaration and Platform for Action, as contained in Report of the Fourth World Conference on Women, UN Doc. A/CONF.177/20/Rev.1 (1996), para. 14 ('Beijing PFA').

142 Susana Fried, The Indivisibility of Women's Human Rights: A Continuing Dialogue (Rutgers, NJ, 1994); Ursula A. O'Hare, 'Realizing Human Rights for Women' (1999) 21 Human Rights Quarterly 364 at 365. For examples of official endorsement of this use of the term see Vienna POA, Part 1 , para, 18; Beiling PFA, paras. (Dee Viena POA, Part 1, para. 18: Beijing PFA, paras. 213, 216. See further Diane Otto 'Defending Women's Economic and Social Rights: Some Thoughts on Indivisibility and a New Standard of Equality' in Isfahan Merali and Valerie Oosterveld (eds.), Giving Meaning To Economic, Social and Cultural Rights (Philadelphia, 2001), pp. 52-67 at p. 51.

${ }^{143}$ Saskia Sassen, Losing Control? Sovereignty in the Age of Globalisation (New York, 1996), pp. 20-3; Cynthia Enloe, 'Silicon Tricks and the Two Dollar Woman' (1992) 227 New Internationalist 12; Zillah Eisenstein, 'Stop Stomping on the Rest of Us: Retrieving Publicness from the Privatization of the Globe' (1996) 4 Indiana Journal of Global Legal Studies licness from 59 at 68.

144 Brenda Cossman, 'Reform, Revolution, or Retrenchment? International Human Rights in the Post-Cold War Era' (1991) 32 Harvard Journal of International Law 339; Anne Orford, developments prompted and, in turn, were sustained by a growing literature of feminist scholarship in the field of international human rights law. ${ }^{145}$ The strategy was informed largely by radical feminist perspectives, which understand 'gender' as a social category that is underpinned by 'sex' as a natural category, as in the UN definition. Drawing again on Olsen's typology, radical feminism, particularly in its cultural strands, accepts the 'sexualization' of gender dualities but seeks to challenge, even reverse, their 'hierarchization' by revaluing the 'feminine."

The first of the two main goals of the women's-rights-are-human-rights $(1)$ strategy, to have gender-specific forms.of rights violations recognized as violations of universal human rights, illustrates how the strategy embraces the sexualized dichotomies of dominant gendered dualisms, seeking their revaluation rather than their disruption. The focus has been on rights connected to a particular set of 'sexed' issues, notably gendered violence, reproduction and, to a lesser extent, sexuality. Women and gender tend to be conflated so that men's analogous gendered injuries are excluded, for example, if men or boys were specifically targeted for rape in war. The narrow focus tends to emphasize women's vulnerability, rather than their agency (re)fostering protective and imperial responses. Giving priority to 'sex' as a category of oppression also risks reproducing essentialist ideas about women, which are consistent with oppressive gender dualities. ${ }^{147}$ Not surprisingly, this essentialism has been roundly criticized by many feminists of colour from inside and outside the West. ${ }^{148}$ A further problem

'Contesting Globalization: A Feminist Perspective on the Future of Human Rights' (1998) 8 Transnational Law and Contemporary Problems 172.

145 See for example Dorinda G. Dallmeyer (ed.), Reconceiving Reality: Women and International Law (Washington DC, 1993); Rebecca J. Cook (ed.), Human Rights of Women: tional Law (Washington DC, 1993); Rebecca J. Cook (ed.), Human Rernational Perspectives (Philadelphia, 1994); Julie Peters and Andrea Wolper (eds.), Women's Rights, Human Rights: International Feminist Perspectives (New York, 1995); Kelly D. Askin and Dorean M. Koenig (eds.), Women and International Human Rights Law (3 vols., New York, vol. I 1999, vol. II 2000, vol. III 2001).

146 Olsen, 'Feminism and Critical Legal Theory', pp. 203-4. See for example Carol Gilligan, In a Different Voice: Psychological Theory and Women's Development (Cambridge, MA, 1982); Nell Noddings, Caring: A Feminist Approach to Ethics and Moral Education (Berkeley, 1984); Sara Ruddick, Maternal Thinking: Toward a Politics of Peace (Boston, 1989).

147 Catharine A. MacKinnon, 'Feminism, Marxism, Method, and the State: An Agenda for Theory' (1982) 7 Signs 515; Catharine A. MacKinnon, 'Feminism, Marxism, Method, and the State: Toward Feminist Jurisprudence' (1983) 8 Signs 635.

148 Harris, 'Race and Essentialism'; Marlee Kline, 'Race, Racism, and Feminist Legal Theory' (1989) 12 Harvard Women's Law Journal 115; Chandra Talpade Mohanty, 'Under Western Eyes: Feminist Scholarship and Colonial Discourses' in Chandra Talpade Mohanty, Ann Russo and Lourdes Torres (eds.), Cartographies of Struggle: Third World Women and the Politics of Feminism (Bloomington, IN, 1991), pp. 51-80. 
with the narrow set of 'sexed' issues is that women's economic and political disadvantage gets left off the agenda.

Attempts to promote women's reproductive and sexuality rights, as a result of the new strategy, have met considerafle resistance, ${ }^{149}$ especially from many religious groups who have taken up the cudgel in their , efforts to keep sex/gender restricted to a biological category. ${ }^{150}$ This backlash was evident at the Beijing Conference and has continued since then, preventing further advances towards women's equality in family relations and threatening regressions. By comparison, the anti-violence agenda has achieved extraordinary successes, ${ }^{151}$ which have spilled over into other areas of international law. ${ }^{152}$ One early demonstration of its success was the adoption of the Declaration on the Elimination of Violence against Women (DEVAW) by the UN General Assembly. ${ }^{153}$ Yet the DEVAW does not recognize violence against women as a violation of human rights because of states' concerns that to do so would water down their universality ${ }^{154}$ This position - that women's specific rights are not universal directly echoes the views of members of the CHR in the 1940s when CSW representatives argued for the explicit inclusion of women's rights in the UDHR. Instead, violence-against-women is understood as a 'barrier' to women's enjoyment of human rights. This leaves DEVAW's subjects still marginalized in the discourse of universality, needing special measures for their protection rather than human rights, Nepal's new restrictions on the ability of women to travel overseas, for example, were defended as a measure to protect them from trafficking, ${ }^{155}$ illustrating the ease with which protective narratives can justify the denial of women's enjoyment of

149 Sarah Y. Lai and Regan E. Ralph, 'Female Sexual Autonomy and Human Rights' (1995) 8 Harvard Human Rights Journal 201; Alice M. Miller, AnnJanette Rosga and Meg Satterthwaite, 'Health, Human Rights and Lesbian Existence' (1994) 1 Health and Human Rights 428. Doris E. Buss, 'Robes, Relics and Rights: The Vatican and the Beijing Conference on
Women' (1998) 7 Social and Legal Studies 339; see further Center for Reproductive Law and Policy, 'The Holy See at the United Nations: An Obstacle to Women's Reproductive (accessed I November 2005) 2000), http://www.reproductiverights.org/pub_bp.html\#un (accessed I November 2005).

${ }^{151}$ O'Hare, 'Realizing Human Rights for Women'

324 International Review of the Red Cross 421; Kernational Humanitarian Law' (1998) 324 International Review of the Red Cross 421; Kelly Dawn Askin, War Crimes ngainst Macklin, 'Refugee Women and the Imperative of Caunals (The Hague, 1997); Audrey Quarterly 213.
. Women and the Imperative of Categories' (1995) 17 Human Rights 153 QuA

154 GA Res. 48/104, UN Doc. A/RES/48/104, 20 December 1993.

Dianne Otto, 'Violence against Women: Something Other than a Human Rights

Violation?' (1993) 1 Australian Feminist Law Journal 159 at 161-2.
t5.5 Kapur, 'Tragedy of Victimization Rhetoric', pp. 6-7. human rights, and revealing a disturbing resonance between the feminist $\triangle \mathrm{AO}$ anti-violence agenda and conservative ideas about gender. This resonance is one way to account for the successes of the strategy.

The focus on women's gendered 'injuries' has had the effect of giving new life to imperial as well as protective subjectivities. As Ratna Kapur explains, the violence-against-women model establishes a 'thoroughly disempowered and helpless' female subject whose diversities are represented as aggravating circumstances of oppression, rather than as a positive mark of the rich multiplicity of women's histories and struggles. ${ }^{156}$ Although violence against women has been identified as a universal phenomenon, the focus has been to condemn certain 'uncivilized' practices in developing countries, such as genital surgeries ${ }^{157}$ and dowry murders, ${ }^{158}$ which produces anew the 'native victim' of her 'uncivilized' culture, whom Western feminists can speak for, rescue and rehabilitate, this time through extending the civilizing reach of human rights law.

The second goal of the women's-rights-are-human-rights strategy was to refocus feminist attention back on the general human rights instru- get if regin ments by promoting the 'mainstreaming' of women's human rights. Main- wo streaming in the UN is understood as consciously considering and taking into account women's, as well as men's, concerns and experiences 'so that women and men benefit equally and inequality is not perpetuated. ${ }^{\prime 59}$ The ultimate goal is identified as achieving women's equality, but this critical element is often lost in bureaucratic translation, reducing the process to a technocratic efficiency exercise. ${ }^{160}$ Gender mainstreaming has been widely endorsed, ${ }^{161}$ and has led to a flurry of activity across the UN system, despite strong resistance from many quarters. ${ }^{162}$ For their part, the chairpersons of the human rights treaty committees affirmed 'that all

156 Ibid., p. 10.

157 See for example Isabelle R. Gunning, 'Arrogant Perception, World-Travelling and Multicultural Feminism: The Case of Female Genital Surgeries' (1991-2) 23 Columbia Human Rights Law Review 189.

158 Kapur, 'Tragedy of Victimization Rhetoric', pp. 13-18.

159 Coordination of the Policies and Activities of the Specialized Agencies and Other Bodies of the United Nations System: Mainstreaming the Gender Perspective into all Policies and Programmes in the United Nations System (adopted by Economic and Social Council 18 July 1997), UN Doc. E/1997/66, as quoted in Office of the Special Adviser on Gender Issues and Advancement of Women, 'Gender Mainstreaming: An Overview' (2002), http://www.un.org/womenwatch/osagi/pdf/e65237.pdf (accessed I November 2005).

160 Sandra Whitworth, Men, Militarism, and UN Peacekeeping: A Gendered Analysis (Boulder, CO, 2004), p. 126; Jacqui True, 'Mainstreaming Gender in Global Public Policy' (2003) 5 International Feminist Journal of Politics 368.

161 Vienna POA, Part II, paras. 37, 42; Beijing PFA, paras. 221, 325.

162 Anne Gallagher, 'Ending Marginalisation: Strategies for Incorporating Women into the UN Human Rights System' (1997) 19 Human Rights Quarterly 283; Felice D. Gaer, 
human rights contained in the international human rights instruments apply fully to women and that the equal enjoyment of those rights should be closely monitored,' ${ }^{163}$ acknowledging indirectly that women had in fact been excluded, just as the CSW members had feared in 1948. Later, the chairpersons endorsed a set of six recommendations which sought to fully integrate gender perspectives into their working methods. ${ }^{164}$ In effect, they were belatedly agreeing to incorporate the pioneering work of the CEDAW Committee, aimed at developing the concept of substantive equality and feminizing the subject of human rights law, into the work of the other treaty committees. This was a step pregnant with possibilities.

One outcome of the treaty bodies chairpersons' recommendations has been the development of General Comments that promote more effective coverage of women's rights. The Human Rights Committee (HRC), which monitors the ICCPR, adopted General Comment 28 on equality between men and women in $2000,{ }^{165}$ while the Committee on Economic, Social and Cultural Rights (CESCR), which monitors the ICESCR, adopted General Comment 16 in 2005 after a long process that revealed deep disagreement about the nature of sex inequality. ${ }^{166}$ The Committee on the Elimination of Racial Discrimination, which monitors the International Covenant on the Elimination of Racial Discrimination (ICERD), also adopted General Recommendation XXV on the gender-related dimensions of racial discrimination in $2000 .{ }^{167}$ While the General Recommendation takes a bold lead in grappling with intersectional gender discrimination and employing the language of 'gender', ${ }^{168}$ for present purposes I will confine my discussion to the General Comments interpreting the covenants.

The HRC's General Comment 28 borrows something from all of the feminist inclusion strategies I have discussed, adopting a substantive approach to women's equality and ensuring women's specific rights are

'Mainstreaming a Concern for the Human Rights of Women: Beyond Theory' in Marjorie Agosín (ed.), Women, Gender, and Human Rights: A Global Perspective (New Brunswick, NJ 2001), pp. 98-122.

163 Report of the Fifth Meeting of Persons Chairing the Human Rights Treaty Bodies, UN Doc. A/49/537 (19 October 1994), para. 19.

164 Effective Implementation of International Instruments on Human Rights, UN Doc. A/50/505 (4 October 1995), paras. 34(a)-(f).

${ }_{165}$ HRC, 'General Comment 28' (29 March 2000), UN Doc. CCPR/C/21/Rev.1/Add. 10.

Letter to CESCR, from Women's Economic Equality Project and Women's Working Group ESCR-Net, 28 April 2004 (copy on file with author). See 'Montréal Principles on Women's Economic, Social and Cultural Rights' (2004) 26 Human Rights Quarterly 760.

167 CERD, 'General Recommendation XXV' (20 March 2000), as contained in UN Doc. HRI/GEN/1/Rev.5.

${ }^{168}$ Otto, “'Gender Comment"', pp. 30-3. explicitly recognized as universal. The Comment works its way through each of the ICCPR rights, reimagining the subject as a woman and, in the process, feminizing civil and political rights. For example, with respect to the right to life (Article 6), the General Comment states that:

States parties should provide data on birth rates and on pregnancy - and childbirth-related deaths of women. Gender-disaggregated data should be provided on infant mortality rates. States parties should give information on any measures taken by the State to help women prevent unwanted pregnancies, and to ensure that they do not have to undergo life-threatening clandestine abortions. States parties should also report on measures to protect women from practices that violate their right to life, such as female infanticide, the burning of widows and dowry killings. The Committee also wishes to have information on the particular impact on women of poverty and deprivation that may pose a threat to their lives. ${ }^{169}$

This interpretation is ground-breaking. It includes the 'sexed' issues that the women's-rights-are-human-rights strategy has been concerned with, for example in identifying backyard abortions as a threat to the right to life, but it does not confine itself to these issues, recognizing that 'poverty and deprivation' may also pose a threat to women's right to life. Each other ICCPR article is interpreted in a similarly woman-centred manner. For example, domestic violence is recognized as a form of torture (Article 7), ${ }^{170}$ a husband's marital powers to restrict women's freedom of movement constitutes a violation of the right to freedom of movement (Article 12), ${ }^{171}$ and conditioning the exercise of reproductive rights on a husband's authorization is a violation of the right to privacy (Article 17). ${ }^{172}$ The HRC has followed up the adoption of General Comment 28 by consistently questioning States Parties about issues such as unsafe abortions, domestic violence, stereotyped gender attitudes and gender discrimination in the enjoyment of rights, in its examination of States Parties' periodic reports. ${ }^{173}$ The questioning has promoted women's equality as a substantive concept.

However, the Comment's focus on women's difference from men means that the challenge to the sexualization of gender dualisms that formal equality presents has entirely disappeared. Indeed, all the dangers that attend the inclusion of women by reference to their specificities remain.

\footnotetext{
${ }^{169}$ HRC, General Comment 28, para. $10 . \quad{ }^{170} \mathrm{Ibid}$., para. 11.

$171 \mathrm{Ibid}$., para. $16 .{ }^{172} \mathrm{Ibid}$., para. 20.

${ }^{173}$ See generally the Concluding Observations of the Human Rights Committee since April 2000 .
} 
The extensive cataloguing of women's injuries and disadvantages, while clearly necessary for making women's human rights abuses legally cognizable, emphasizes women's helplessness rather than their agency. This has the effect of reaffirming the masculinity of the universal subject who needs no special enumeration of his gender-specific injuries. The catalogue reifies the differences between women and men, reproducing not only the familiar dualistic gender sexualizations, but also the same gender hierarchies. Some of the examples of women's specific violations also serve to resurrect protective and imperial subjectivities. The central place given to non-Western practices that violate women's right to life, for example, revitalizes the imperial victim subject. The unresolved feminist conundrum is well illüstrated: in reflecting women's present gendered experience of human rights violations, human rights law repeats the marginalizing gender tropes that entrench and naturalize women's inequality.

The efforts of the CESCR to elaborate a General Comment on equality between women and men in the enjoyment of economic, social and cultural rights raises a different set of problems. The Committee's drafts approached sex inequality as a problem without a hierarchy; treating men as if they were as disadvantaged by gender inequality as women. ${ }^{174}$ While this approach could be very interesting if men's gender disadvantage was understood to arise from their dominant gender position, this is hard to conjure up and is not, in any event, what the CESCR has in mind. Rather, the drafts were an example of gender mainstreaming 'with a vengeance, ${ }_{1}^{175}$ by which I mean that women's gender disadvantage and the end goal of realizing women's equality have been lost in translation. Despite being an improvement on the earlier drafts, the final Comment still fails to fully recognize women as the disadvantaged group vis-à-vis men, ${ }^{176}$ illustrating one of the concerns that many feminists have with the shift to the terminology of 'gender'. While the discourse of gender has the advantage of acknowledging the relational quality of the gender tropes that privilege men and disadvantage women, the concern is that this creates an opportunity for men's interests to dominate once they have been discursively admitted into the hard-won spaces carved out for women to address their exclusion. ${ }^{177}$ This illustrates how easily the misuse of the language of 'gender' can lead to a denial of the systemic nature of women's disadvantage.

174 CESCR, Draft General Comment 16, April 2004 (copy on file with author).

${ }_{176}$ See MacKinnon, 'Agenda for Theory'; 'Toward Feminist Jurisprudence'.

176 CESCR, 'General Comment 16' (13 May 2005), UN Doc. E/C.12/2005/3, paras. 5, 8.

177 Sally Baden and Anne Marie Goetz, 'Who Needs [Sex] When You Can Have [Gender]? Conflicting Discourses on Gender at Beijing' in Cecile Jackson and Ruth Pearson (eds.) Feminist Visions of Development: Gender Analysis and Policy (London, 1998), pp. 19-38 at p. 21 .
While General Comment 28's account of gender reveals how strongly intact the sexualizations and hierarchies of gender have remained, despite over fifty years of feminist engagement with human rights law, the CESCR's Comment reveals the disastrous consequences for women if they are papered over. The HRC's reinvigoration of marginalized women's subjectivities highlights the question that has haunted my entire discussion - whether a focus on women's specificities, in the framework of universality, will ever achieve women's full inclusion in universal representations of humanity, because it is those very specificities against which the privileged figure of the masculine universal is defined. Yet to ignore women's specificities, as in the CESCR's Comment, is to misrepresent the reality of women's gendered disadvantage. This dynamic suggests that, paradoxically, the cost of women's 'inclusion' may be their continuing marginalization; that the project of disrupting gender hierarchies through human rights law may be impossible. That is, unless the new moves towards the language of gender can be utilized in the spirit of its emancipatory origins. Could the recognition that sex/gender are entirely social categories open new possibilities for challenging not only the rigid sexualizations of gender dualities, but also their hierarchies? It is to this possibility that I now turn.

\section{A new strategy proposal: re-scripting sex as shifting and multiplicitous}

As I have shown, the history of the engagement of women's rights advocates with human rights law highlights a conundrum; feminist inclusion strategies have reproduced unequal relations of gender power in their efforts to make women's gender-specific human rights violations legally cognizable and achieve women's full inclusion in a universal discourse. The method of making the 'gendered human rights facts' of women's lives legally actionable repeats the hierarchical gender scripts that produce the gendered violations in the first place. Unless feminist strategies can be re-scripted to disrupt the circular restaging of women's marginalization, the most that will be achieved will be some uncertain improvements in the conditions of that marginalization, which will always be vulnerable to reversal because the underpinnings of women's inequality will not have been disrupted. It could be argued that such incremental improvements will multiply and constitute eventually a significant challenge to the persistence of male privilege because the 'gendered human rights facts' will have changed, and this may be right. However, feminists have been engaged in this project for at least the past century and the 
progress to date is not encouraging. Gender hierarchies have not only remained strongly naturalized, but the tropes that they rely upon seem barely to have shifted, despite the recent history of determined contestation by feminist human rights advocates. Karen Engle's conclusion from her survey of the impact of women's human rights strategies in 1992 is still apt; while the masculinist core may have been shaken, it remains, and ' $[w]$ omen are still on the periphery. ${ }^{178}$ In fact, backlashes from fundamentalist forces are threatening many of the incremental gains that have been made. ${ }^{179}$

So, how could the re-scripting of gender in human rights law be done? By what means could emancipatory gender subjectivities be produced? What alternatives are there to the abstract universal subject and his female 'others'? We might begin by thinking about existing feminist strategies and whether they could be extended or reoriented. For example, what would be the effect of building on the women's-rights-are-human-rights-strategy and fully reflecting the idea that there are two sexes in human rights law, instead of trying to force the masculine universal to be more gender inclusive? This would involve creating the universal as a 'double subjectivity', as Luce Irigaray has suggested, with two sets of sexually specific rights. ${ }^{180}$ Irigaray's argument is that the feminine will retain its object status unless relations between men and women are changed so that they have access to genuinely intersubjective relations, and that this will only occur if women are fully subjectivized. Her proposal, then, is that the law be 'sexed dualistically'; ${ }^{181}$ that a distinctive and socially valued women's culture be recognized by according women rights of 'being' that are sexually specific, like rights to guardianship of the home, to motherhood and virginity, to equal institutional representation and to economic resources. ${ }^{182}$ Only as full bearers of rights will women achieve the status of full subjects, and only then will equality be possible. However, this approach would

${ }^{178}$ Engle, 'International Human Rights and Feminism', p. 610.

179 On 4 April 2004, the Special Rapporteur on Violence against Women warned the CSW of 'alarming trends towards political conservatism and backlash which threatened the gains made thus far in the global women's human rights agenda': as reported in Women' International League for Peace and Freedom, 1325 Peacewomen 2004, http://www.peacewomen.org/news/1325News/1325ENewsindex.html (accessed November 2005).

${ }^{180}$ Luce Irigaray, Thinking the Difference: For a Peaceful Revolution (trans. Karin Montin New York, 1994), chapter 3.

181 Discussed in Davies, 'Taking the Inside Out', p. 27.

${ }^{182}$ Luce Irigaray, Je, Tu, Nous: Towards a Culture of Difference (trans. Alison Martin, London, 1993), chapters 9 and 10. exacerbate the problems of essentialism and the lack of attention to other hierarchies of power which attend the women's-rights-are-human-rights strategy. It would also fix gendered subjects firmly within the existing sexualized dichotomies, strengthening the idea of gender as a natural category, rather than rejecting it.

A second option would be to seek to particularize the masculine in much the same way as the feminine has been made specific. The CESCR's problematic General Comment is suggestive of this approach, although this was not its intention. What $I$ have in mind is reimagining men as injured by the hierarchies of gender; casting them as the victims of dominating forms of masculinity that give rise to human rights claims. Conscription into the armed services is one example of the enforcement of a particular militarized form of masculinity, which many men find coercive and oppressive. While human rights law currently provides a remedy for conscientious objectors, this does not extend to those who object to compulsory service as a form of gender injury. In fact, the masculinist discourses that support war construct such objecting men as suffering a different kind of gender injury; as being too feminized to be 'real men'. ${ }^{183}$ If human rights law could produce, instead, the militarized man as the injured subject and valorize the objector as an expression of emancipated masculinity, the discourses that legitimate war, which resemble the scripts that repeat women's marginalization in human rights law, would be seriously disrupted.

More generally, outside the example of military conscription, it seems incorrect to describe men as 'injured' by their gender privilege. While men's experience of gender power may involve pain and alienation, ${ }^{184}$ this kind of injury cannot be equated with the injury that comes from lack of gender privilege, especially because women do not benefit from men's gender injuries. In fact, if the injuries associated with masculinity were to be enumerated - like those that result from exercise of the 'masculine' attributes of competitiveness and aggression - the list would bear a superficial resemblance to the UDHR, while differing in the important sense of identifying the cause of the injuries as dominating and imperial forms of masculinity. So, although there are many disruptive possibilities in the idea that men's injuries resulting from their male privilege could be

${ }^{183}$ Carol Cohn, 'War, Wimps, and Women: Talking Gender and Thinking War' in Miriam Cooke and Angela Woollacott (eds.), Gendering War Talk (Princeton, 1993), pp. 227-48.

184 Michael Kaufman, 'Men, Feminism, and Men's Contradictory Experiences of Power' in Harry Brod and Michael Kaufman (eds.), Theorizing Masculinities (London, 1994), pp.142-63. 
made legally cognizable, turning the gaze back on men in this way runs the risk of leaving women on the periphery all over again by shifting the focus away from the oppressive effects of gender hierarchies on women. Particularizing men's injuries could also serve to reinforce rather than dismantle male privilege. At the same time, feminist campaigns will never succeed unless they take account of the relational quality of gender; the need to change both male and female subjectivities. The recent efforts of the CSW to promote discussion about the role of men and boys in achieving gender equality is a useful initiative in this regard. ${ }^{185}$ For as long as masculinity is conceptualized as a dominant form of power in human rights law, the female subject will remain trapped in the gender-subordinate position. This is the reverse side of the feminist conundrum I have already outlined.

A further option that emerges from thinking about building on existing strategies is to work towards inverting the existing gender scripts so that, for example, men are produced as nurturers and carers and women as breadwinners. This idea extends the formal equality framework, which disrupts the dualistic sexualization of gender by granting women the same rights as men if they undertake activities that have traditionally been classified as 'masculine'. If these disruptions can be made to work both ways, by granting men who engage in domestic work the same human rights as women, the hierarchy of gender will also be challenged. Such reversals have important symbolic effects in that they immediately complicate gender identities and upset the naturalness of the dominant gender scripts. However, where such reversals have had some effect on social practices, all too often the privilege associated with masculinity has remained attached to male bodies. Therefore, the strategy of reversals presents only a limited challenge to the arrangement of gender as hierarchy because gendered power, or the lack of it, follows gendered bodies. Nevertheless, gender reversals are helpful in revealing the fluidity of sex and showing how gendered bodies as well as occupations are fully social productions.

However, building on existing strategies still avoids the recognition that sex/gender is entirely socially produced. Indeed, if the persistent hierarchies produced by dualistic gendered subjectivities - protective and vulnerable, rescuing and injured, autonomous and dependent - are to be displaced, gender must be re-scripted as something other than a dichotomy;

${ }^{185}$ See Division for the Advancement of Women, The Role of Men and Boys in Achieving Gender Equality: Report of the Expert Group Meeting (12 January 2004), UN Doc. EGM/MEN-BOYS-GE/2003/REPORT. as multiplicitous rather than as dualistic. The feminist project of denaturalizing sex needs to be taken to its logical conclusion, which is to detach sex/gender entirely from bodily parts. The notion of gender 'hybridities' is a useful way to develop this idea; that human beings need to be understood as constituted by a multiplicity of ideas and practices that are culturally associated with masculinity and femininity, rather than predetermined by biology as either 'male' or 'female'. Gender identity, then, becomes the hybrid result of choices and desires that are not tied to male, female, transgendered, butch, femme, queer, eunuch or any other body types, which are, in any event, also social constructions. Such a diversity of gendered subject positions would make it impossible for the present dualistic sexualizations and hierarchies of gender to survive. If hybrid gender subjectivities could be admitted into the legal lexicon, the full range of sex/gender possibilities would be opened to all human beings as never before and the dualistic models of gender equality would be superseded.

But I am jumping too far ahead. The rejection of gender as dichotomy and hierarchy would also mean the loss of conceptual tools that are necessary to make legal sense of the 'gendered human rights facts' of the present. Fully embracing sex/gender as a social category would threaten erasure of the female subject produced by conditions of gender inequality and make nonsense of gender-specific human rights. It may also still reassert the masculine as the universal in the image of the hybrid. Finally, it would erase the categories that are presently essential for feminist political action and leave subjugated gender subjectivities without language to express their human rights claims.

Pulling back from, but not abandoning, the idea of gender hybrids, possible point of departure is suggested by Ratna Kapur's 'resistive subjects. ${ }^{186}$ She proposes that legal strategies be built on the idea of law as a site of discursive struggle and 'normative challenge', instead of looking to law to promote gender equality by producing more rights. ${ }^{187} \mathrm{Her}$ strategy, or at least my application of it to the problems I am considering here, suggests foregrounding those subjects who disrupt the presently sexed and imperial order of human rights law; those chaotic, disorderly and demonized 'others' who exist on the fringe of human rights law and 'civilized' society. Kapur's peripheral subjects include transnational migrants (legal and illegal), Muslims, homosexuals and sex workers, ${ }^{188}$ and there are many more such candidates. They present normative

${ }_{186}$ Kapur, 'Tragedy of Victimization Rhetoric', pp. $29-34 . \quad{ }^{187}$ Ibid., p. 29. 188 Ibid., pp. 31-3. 
disruptions, as in the case of the migrant woman who chooses to move, which belie marginalizing assumptions about women as tied to the home and family by oppressive cultural traditions. ${ }^{189}$ If feminist human rights strategies were constructed on the normative challenges presented by such disruptive subjects, they would pose a serious challenge to the biologism of sex and the dichotomies and hierarchies that have been built on the myth of naturalness.

Therefore, it is premature to conclude that women's full inclusion in humanity is impossible. If feminist engagement with human rights law is translated into a project committed to completely denaturalizing sex/gender and reimagining gender as hybrid and diverse rather than dualistic, then it has barely begun and it is hard to predict what new opportunities and insights will emerge. Re-scripting sex as shifting and multiplicitous needs to be an interdisciplinary endeavour that has the courage to draw on new theoretical paradigms, as well as old histories. At a time when many states are dogmatically embracing naturalisms in defence of traditional family formations and fundamentalist religious precepts, human rights law offers an increasingly embattled secular space for discursive contestation of unequal relations of gender power as well as new understandings of power. Hope is not lost, despite old and new challenges to critical and emancipatory thinking. While feminist human rights advocates need to be wary of legal constructions that cast women as victims, as vulnerable and in need of protection, and as only needing to enjoy the same rights as men, a new language of human rights must be created that does not allow such injurious slippages.

189 Ibid., p. 32. 


\section{University Library}

\section{- M M N E R VA A gateway to Melbourne's research publications}

Minerva Access is the Institutional Repository of The University of Melbourne

Author/s:

OTTO, DIANNE

Title:

Lost in translation: Re-scripting the sexed subjects of international human rights law

Date:

2006

Persistent Link:

http://hdl.handle.net/11343/25562 